Ann. Biol. anim. Bioch. Biophys., 1977, 17 (6), 1087-1094.

\title{
Steroid 3p-ol-dehydrogenase activity in the largest healthy and atretic follicles in the human ovary during the menstrual cycle
}

\author{
par A. GOUGEON \\ with the technical assistance of Marylène GUILLOU
}

Université Paris Sud, Laboratoire de Physiologie de la Reproduction humaine, Gynécologie-Obstétrique, Hôpifal Antoine-Béclère, 157, rue de la Porte de Trivaux, 92141 Clamart, France.

Summary. Steroid $3 \beta-0$-Dehydrogenase $(3 \beta-0 \mid-S D H)$ activity of large ovarian follicles in woman was analysed by histoenzymological method. $3 \beta$-ol-SDH activity was strong $(+++)$ in the theca interna of the preovulatory follicle until ovulation, with a maximum (very strong: ++++ ) at the same time as the plasma estradiol peak. Very strong $(++++)$ $3 \beta$-ol-SDH activity appeared in the granulosa after plasma LH surge. In large healthy or atretic non-ovulatory follicles, 3 $\beta$-ol-SDH activity was stronger in the theca interna than in the granulosa where it has never been found at a significant level. No variation in enzymatic activity has been shown during the menstrual cycle in these latter follicles.

\section{Introduction.}

$3 \beta$-ol-SDH has a well defined role in steroid biosynthesis; it catalyses, among others, the conversion of pregnenolone to progesterone. Analysis of the variable activity of this enzyme is thus of considerable interest in studying the synthesis sites and factors regulating sex steroid production.

The presence of this enzyme in the human ovarian follicle has been revealed by many authors using a hystoenzymological technique (lkonen ef al., 1961 ; Deane et al., 1962 ; Chieffi et al., 1965 ; Fienberg and Cohen, 1965 ; Taki et al., 1966 ; Jones ef al., 1968 ; Friedrich et al., 1974 ; Kerin ef al., 1976). Incomplete analysis of follicles, taken at random without reference to the menstrual cycle, may explain why the results obtained have often been disappointing.

The theca is reported to have only moderate $3 \beta-$ ol-SDH activity, this activity being seen exceptionally in the granulosa even in preovulatory follicles.

There are three types of large, functionally different follicles in the human ovary 
(Bomsel-Helmreich ef al., in press) : preovulatory follicles and large healthy or atretic non-ovulatory follicles. In this report, the level of $3 \beta-0 \mathrm{l}-\mathrm{SDH}$ activity and its variations in theca interna and granulosa of the largest ovarian follicles in woman are analyzed throughout the menstrual cycle.

\section{Material and methods.}

Sampling. Fifty-three follicles from 5 to $27 \mathrm{~mm}$ in diameter were sampled at varying stages of the menstrual cycle in 46 subjects undergoing laparotomy for various gynecologic disorders, not directly related to ovarian pathology. Peripheral blood was generally obtained 1 and 2 days prior to surgery, the day of surgery, and the day after. $\mathrm{LH}, \mathrm{FSH}$, estradiol-17 $\beta$ and progesterone were assayed. Five of the subjects received 5000 IU HCG 20 to $40 \mathrm{hrs}$ before laparotomy.

Dating. The period of the cycle at which follicles were obtained was determined by data on plasma FSH, LH, estradiol-17 $\beta$ and progesterone, day of last menses and BBT. The patients had had regular 28 to 30 -day cycles during the months previous to sampling. The highest temporal precision was obtained for the 2 days preceding and following the LH surge (12-hrs precision). This period corresponds to clearcut hormonal event : estradiol-17 $\beta$ peak, the LH and FSH surges, and finally ovulation. Temporal precision is lower for other periods of the cycle (estimated at $36 \mathrm{hrs}$ ) as hormonal levels evolve much slower.

Hisfochemical investigation. $10 \mu \mathrm{m}$-thick cryostat sections of a follicular fragment were incubated for $1 \mathrm{hr}$ in a previously described medium (Gougeon, 1974) derived from Wattenberg's technique (1958) modified by Levy et al. (1959). Not being able to objectively measure the histochemical reaction of $3 \beta-o l-S D H$, we evaluated it as a function of diformazan precipitate density ; it is rated as zero $(-)$, weak $(+)$, moderate $(++)$, strong $(+++)$, very strong $(++++)$ (plate 1$)$.

Hisfology. The rest of each follicle was fixed in Bouin-Hollande fixative, then treated by classical histological techniques.

PLATE I. - Range of 3 3 -ol-SDH activity in the theca interna and the granulosa of ovarian follicles in woman.
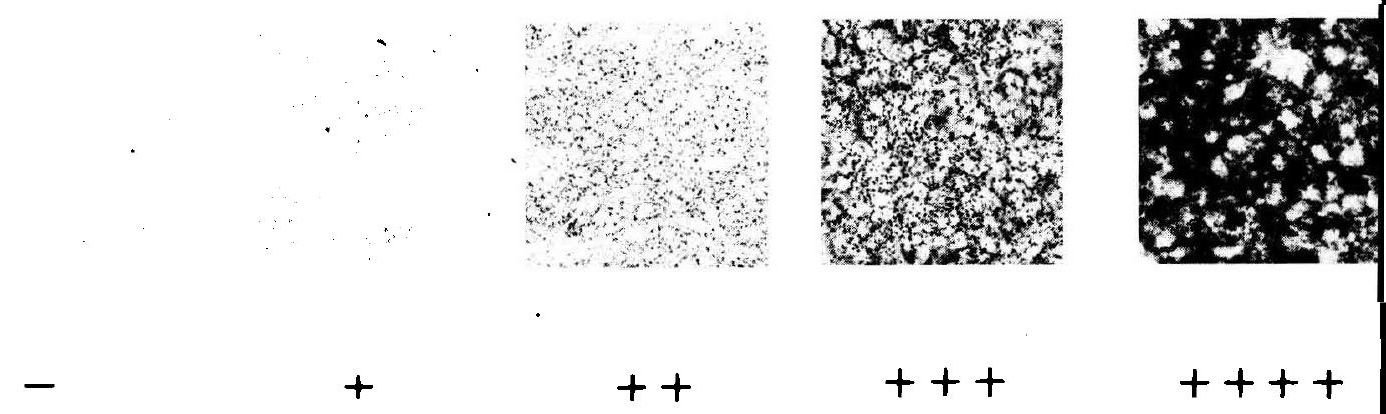


\section{Results.}

The follicular phase has been divided into three parts ( $D 0$ is the day of LH surge) : early follicular phase from D14 to D10, middle follicular phase from D9 to D6, and late follicular phase from D5 to ovulation.

Preovulatory follicles can be identified as early as day 5 before LH peak. Thus, the late follicular phase may also be called the preovulatory phase, which can also be divided into 3 parts : preovulatory phase I from D5 to plasma estradiol peak, preovulatory phase II between the estradiol-17 $\beta$ peak and $\mathrm{LH}$ surge, preovulatory phase III between LH surge and ovulation.

\section{Preovulatory follicle (31).}

This type of follicle is distinguished by its morphology and a remarkable histological evolution (Bomsel-Helmreich ef al., in press), as well as by the development of its steroidogenic potentialities during the preovulatory phase.

During preovulatory phase I, $3 \beta$-ol-SDH is strong $(+++)$ in the theca interna and moderate $(++)$ in the granulosa ; during the plasma estradiol peak this activity becomes very strong $(++++)$ in the theca (photo 1). During preovulatory phase II, a strong $(+++)$ activity appears in the granulosa which then equals that of the theca interna (photo 2). During preovulatory phase III, $3 \beta-\mathrm{ol}-\mathrm{SDH}$ activity is very strong $(++++)$ in the granulosa after LH surge ; it is higher than that in the theca interna which remains strong $(+++)$ (photo 3 ).

In the 5 follicles sampled from 20 to $40 \mathrm{hrs}$ after HCG, $3 \beta$-ol-SDH activity is very strong $(++++)$ in the granulosa and moderate $(++)$ to strong $(+++)$ in the theca interna (photo 4). The activity of these follicles is thus similar to that of unstimulated follicles during phase III.

\section{Non-ovulatory follicles (22).}

Some large, healthy follicles are found during the preovulatory phase. They are presumed to be non-ovulatory since they always co-exist with a preovulatory follicle and have a much smaller diameter.

Atretic follicles are recognized by their high rate of pyknosis. We differentiate early atretic follicles (granulosa hardly altered) from those with marked atresia (desquamated granulosa and degenerate cells).

Fifty percent of the follicles were healthy or in early atresia, and ranged between 5 and $8 \mathrm{~mm}$ in diameter. They were only found during the follicular phase ; examination of seriated cross-sections of 25 whole ovaries seemed to confirm their absence during the luteal phase. The theca interna showed moderate $(++)$ to strong $(+++)$ $3 \beta$-ol-SDH activity, while that enzyme was weakly active $(+)$ in the granulosa (photo 5 ). The slight variation in thecal activity did not depend on the state of the follicle, some follicles in early atresia being more active than healthy ones. These variations also occured independently of the cycle stage at which samples were taken (fig. 1).

Fifty percent of the follicles were in pronounced atresia ; they ranged between 5 to $10 \mathrm{~mm}$ in diameter and were present throughout the menstrual cycle. The theca interna showed weak $(+)$ to moderate $(++)$ 3 $\beta$-ol-SDH activity, while the enzyme 

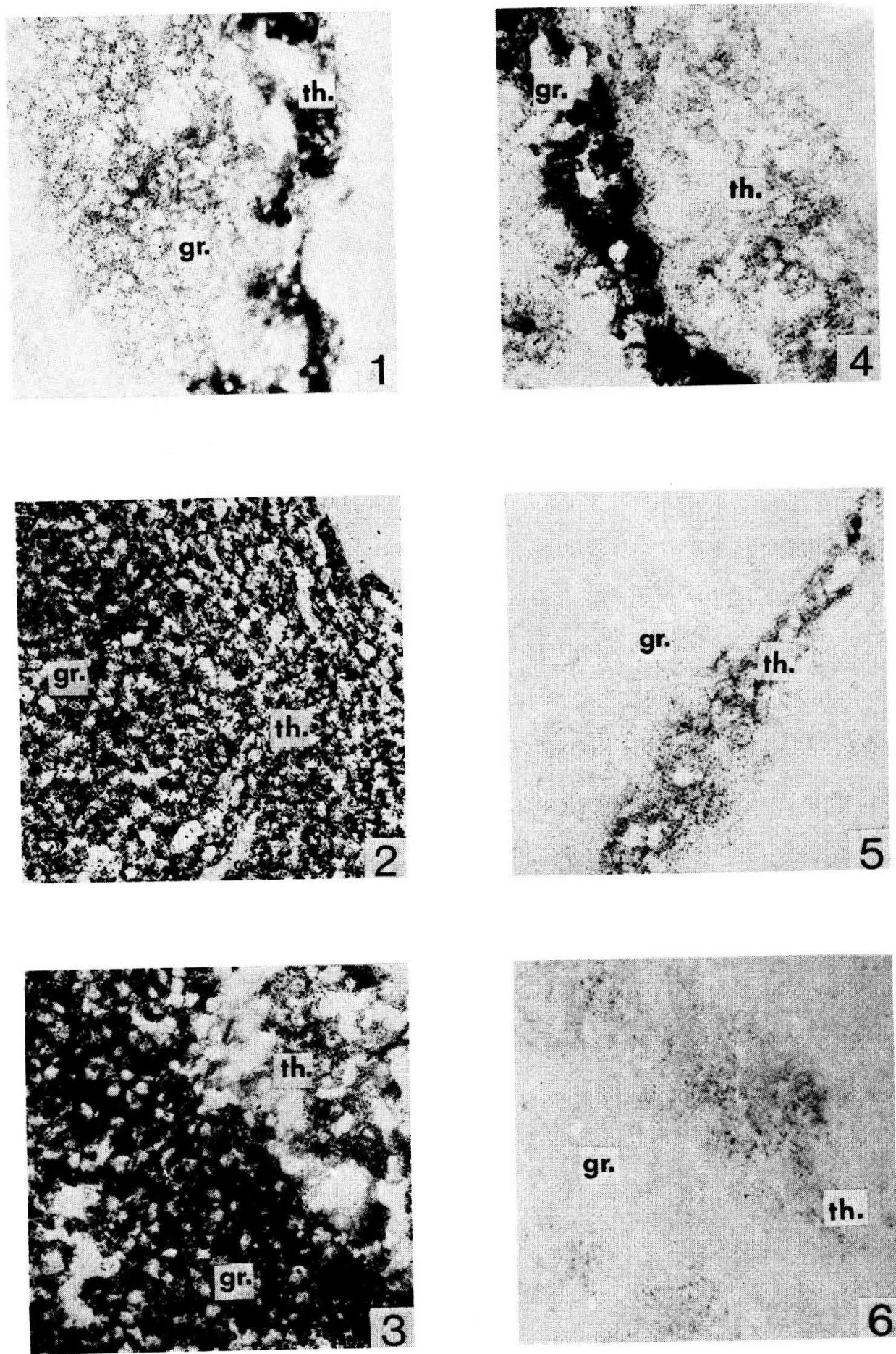


\section{PLATE II}

Steroid-3 $\beta$-ol-dehydrogenase activity in the theca interna and granulosa of large follicles in woman $(\times 145)$.

Photo 1 : Preovulatory follicle during estradiol peak ; very strong activity $(++++)$ in the theca interna, moderate in the granulosa $(+t)$.

Photo 2 : Preovulatory follicle during preovulatory phase II ; strong activity $(+++)$ in the theca interna and granulosa.

Photo 3 : Preovulatory follicle during preovulatory phase III ; very strong activity $(+++t)$ in the granulosa, strong activity $(+++)$ in the theca interna.

Photo 4 : Large follicle $30 \mathrm{hrs}$ after HCG ; very strong activity $(++++)$ in the granulosa, moderate $(++)$ in the theca. This follicle is collapsed.

Photo 5 : Healthy non-ovulatory follicle in preovulatory phase 1 ; moderate activity $(++)$ in the theca interna, weak $(+)$ in the granulosa.

Photo 6 : Large follicle in marked afresia ; weak activity $(+)$ in the theca interna, zero $(-)$ in the granulosa. 
was practically absent (-) in the granulosa (photo 6). No enzymatic activity related to the cycle was detecied in this type of follicle (fig. 1).

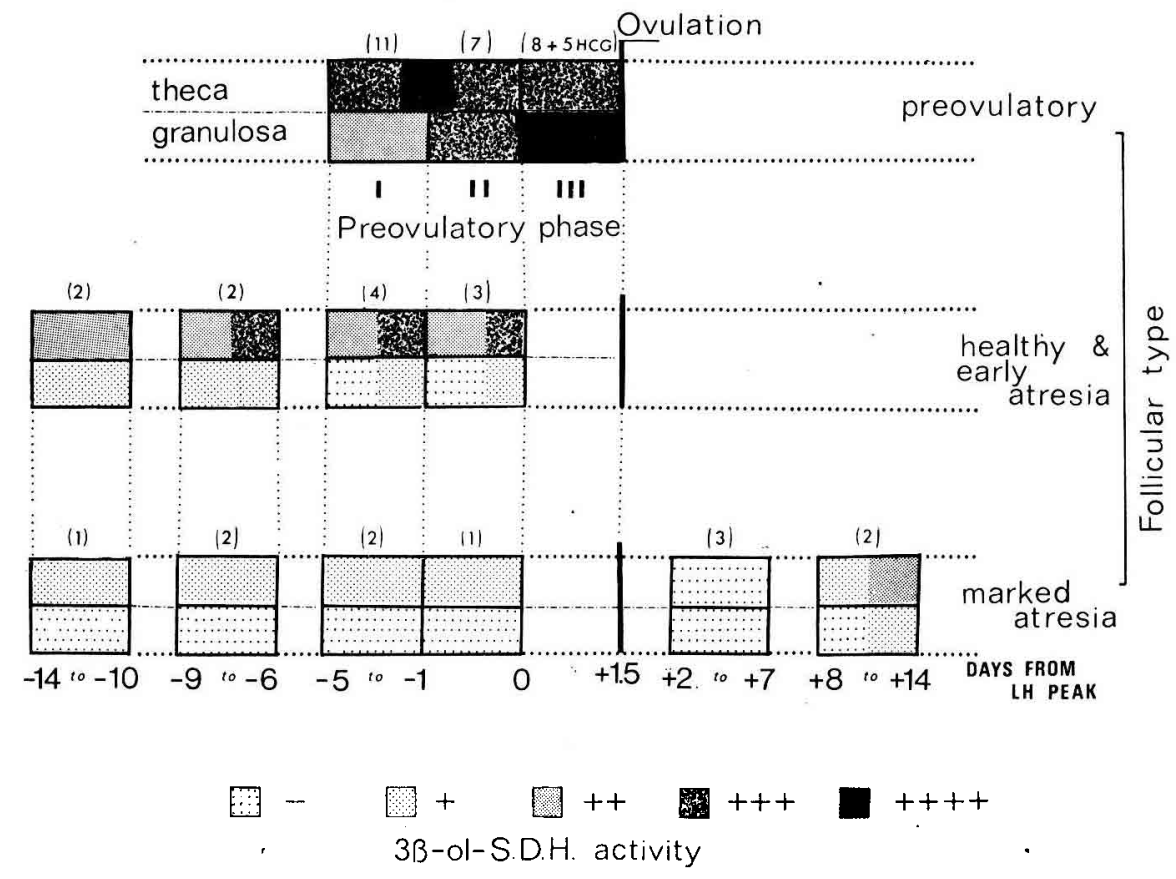

FIG. 1. - Evolution of 33-ol-SDH activity in the theca interna and granulosa of each type of large human ovarian follicle. There is slight individual variation in the reaction of each type of non-ovulatory follicle, but the activity does not vary in relation to cycle date. The length of the strip showing $3 \beta$-ol-SDH activity is proportional to the percentage of follicles presenting that activity. The number of follicles is shown in brackets ( ).

\section{Discussion.}

During preovulatory phase 1 , moderate $(++) 3 \beta$-ol-SDH activity is found in the granulosa of preovulatory follicles. We clearly demonstrate the role of LH surge in stimulating $3 \beta$-ol-SDH activity in preovulatory follicle granulosa. In this tissue, enzymatic activity increases strongly during preovulatory phase II, i.e. during LH surge or after HCG injection.

The appearance of strong $3 \beta$-ol-SDH activity in the granulosa of human preovulatory follicle after the LH surge tends to show that this tissue in responsible for preovulatory progestin synthesis ( $17 \alpha-\mathrm{OH}$-progesterone, pregnenolone, progesterone) These steroids have been demonstrated in the follicular fluid by McNatty et al. (1975), Sanyal ef al. (1974), Friedrich et al. (1974), Kemeter ef al. (1975), Fowler ef al. (1977), Bomsel-Helmreich et al. (in press) and in the peripheral blood by Thorneycroft et al. (1974) and Guerrero et al. (1976).

Friedrich ef al. (1974) were the only authors to find moderate $3 \beta$-ol-SDH activity 
in the granulosa of some preovulatory follicles ; that activity, however, was not stronger than in the theca interna. This difference with our results is probably due to the enzymatic activity loss inherent in the technique of Levy ef al. (1959) used by Friedrich ef al.; a technique which differs from ours as to the steroid solvent used, the incubation medium and the technique and length of incubation.

We have shown that the steroid metabolism of non-ovulatory follicles does not vary with the stage of the menstrual cycle. This observation agrees with those of Bomsel-Helmreich ef al. (in press) showing that estradiol and progesterone levels are low in the follicular fluid of this type of follicle, and do not vary significantly during the menstrual cycle.

We have not found significant $3 \beta-$ ol-SDH activity in atretic follicle granulosa. This is in contradiction with Deane ef al. (1962) who write : $\ll \Delta$-3 $\beta$-hydroxysteroid dehydrogenase activity was normally limited to the theca cells...... In atretic follicles. it also made its appearance in the granulosa. " The morphological features of granulosa degeneration in atretic follicles are such that it is difficult to believe that those cells could have a steroidogenic-like activity. The theca interna present $3 \beta-0$-SDH activity even in very atretic follicles because it degenerates much later than the granulosa.

In conclusion, $3 \beta$-ol-SDH activity is low and steady in large non-ovulatory follicles; these follicles seem to contribute weakly to ovarian steroid synthesis during the human menstrual cycle. $3 \beta$-ol-SDH activity increases in preovulatory follicles until ovulation, first slowly in the theca interna, then suddenly in the granulosa under $\mathrm{LH}$ effect.

Reçu en février 1977.

Accepté en septembre 1977.

Acknowledgements. - We wish to thank the Roussel Laboratories which furnished the steroids free of charge. This work was funded by the Faculty of Medicine, ParisSud, UER Kremlin-Bicêtre and the INSERM (ATP 8 N5 74/29).

We are grateful to Mrs A. Daifuku for editorial assistance.

Résumé. L'activité $3 \beta$-ol-stéroïde déshydrogénase $(3 \beta-0 \mathrm{l}-\mathrm{SDH})$ des plus grands follicules ovariens chez la femme, a été analysée par la technique histoenzymologique.

L'activité $3 \beta-0 /-S D H$ est forte $(+++)$ dans la thèque interne du follicule préovulatoire jusqu'à l'ovulation, avec un maximum (très forte $:++++$ ) pendant le pic d'œstradiol plasmatique. Dans la granulosa de ce type de follicule, la décharge de $\mathrm{LH}$, entraîne l'apparition d'une très forte activité $3 \beta$ ol-SDH. Dans les grands follicules non ovulatoires, sains et atrétiques, l'activité 3 $\beta$-ol-SDH est plus élevée dans la thèque interne que dans la granulosa où elle n'atteint jamais un niveau d'activité significatif. Aucune variation d'activité enzymatique n'a été mise en évidence, pendant le cycle menstruel, dans les follicules non ovulatoires.

\section{References}

BOMSEL-HELMREICH O., GOUGEON A., THEBAULT A., SALTARELlI D., MILGROM E., PAPIERNIK E. Healthy and atretic follicles in the preovulatory phase ; differences in evolution of follicular morphology and steroid content of follicular fluid. J. clin. endocr. Metab. (in press). 
CHIEFFI G., LA TORRETTA G., DEL BIANCO C., TRAMONTANA S., 1965. Distribuzione istochimica delle $3 \beta-, 17 \alpha-$ e $17 \beta$-idrossisteroide deidrogenasi nell'ovario umano nel ciclo mestruale. Arch. Ostet. Gynec., 70, 492-500.

DEANE H. W., LOBEL B. L., ROMNEY S. L., 1962. Enzymatic histochemistry of normal human ovaries of the menstrual cycle, pregnancy and the early puerperium. Am. J. Obsteir. Gynec., 83, 281-294.

FIENBERG R., COHEN R. B., 1965. A comparative histochemical study of the ovarian stromal lipid band, stromal theca cell and normal ovarian follicular apparatus. Am. J. Obstef. Gynec., 92, 958-959.

FOWLER R. E., CHAN S. T. H., WALTER D. E., EDWARDS R. G., STEPTOE P. C., 1977. Steroidogenesis in human follicles approaching ovulation as judged from assays of follicular fluid. J. Endocr., 72, 259-271.

FRIEDRICH F., BREITENECKER G., SALZER H., HOLZNER J. H., 1974. The progesterone content of the fluid and the activity of the steroid $3 \beta$-ol-dehydrogenase within the wall of the ovarian follicles. Acta endocr., 76, 343-352.

GOUGEON A., 1974. Aspects originaux de la glande interstitielle ovarienne chez le hérisson : morphologie, hyperplasie, enzyme de la stéroìdogenèse. Ann. Biol. anim. Biochim. Biophys., 14, 53-66.

GUERRERO R., ASO T., BRENNER P. F., CEKAN Z., LANDGREN B. M., HAGENFELDT K., DICZFALUZY E., 1976. Studies on the pattern of circulating steroids in the normal menstrual cycle. I. Simultaneous assays of progesterone, pregnenolone, dehydroepiandrosterone, androstenedione, cstradiol and œstrone. Acta endocr., 81, 133-149.

IKONEN H., NIEMI M., PESONEN S., TIMONEN S., 1961. Histochemical localization of four deshydrogenase systems in human ovary during the menstrual cycle. Acta endocr., 38, 293-301.

JONES G. E. S., GOLDBERG J. D., WOODRUFF J. D., 1968. Cell specific steroid inhibitions in histochemical 3ß-ol-dehydrogenase activities in man. Histochemie, 14, 131-142.

KEMETER P., SALZER H., BREITENECKER G., FRIEDRICH F., 1975. Progesterone, cestradiol-17 $\beta$ and testosterone levels in the follicular fluid of tertiary follicles and Graafian follicles of human oviries. Acta endocr., 80, 686-704.

KERIN J. F. P., MOOR R. M., SEAMARK R. F., 1976. Human Graafian follicles in tissue culture, correlations between estrogen and progesterone production and the site of $\Delta 5-3 \beta-O H$-steroid dehydrogenase. Theriogenology, 6, 605.

LEVY H., DEANE H. W., RUBIN B. L., 1959. Visualization of steroid 3ß-ol-dehydrogenase activity in tissue of intact and hypophysectomized rats. Endocrinology, 65, 932-942.

MCNATTY K. P., HUNTER W. M., MCNEILLY A. S., SAWERS R. S., 1975. Changes in the concentrations of pituitary and steroid hormones in the follicular fluid of human Graafian follicles throughout the menstrual cycle. J. Endocr., 64, 555-571,

SANYAL M. K., BERGER M. J., THOMPSON I. E., TAYMOR M. L., HORNE Jr H. W., 1974. Development of Graafian follicles in adult human ovary. I. Correlation of estrogen and progesterone concentration in antral fluid with growth of follicles. J. clin. Endocr. Mefab., 38, 828-835.

TAKI I., HAMAMAKA N., MORI M., 1966. Histochemical observations of enzymatic patterns in human ovaries. Am. J. Obstet. Gynec., 96, 388-399.

THORNEYCROFT I. H., SRIBYATTA B., TOM W. K, NAKAMURA R. M., MISHELL Jr D. R., 1974. Measurement of serum LH, FSH, progesterone, $17 \alpha$-hydroxyprogesterone and estradiol $17 \beta$ levels at 4-hour intervals during the periovulatory phase of menstrual cycle. J. clin. Endocr. Metab., 39, 754-758.

WATTENBERG L. W., 1958. Microscopic histochemical demonstration of $3 \beta$-ol-dehydrogenase in tissue sections. J. Histochem. Cyfochem., 6, 225-232. 